\title{
Global economic governance and the challenge facing traditional international law in the 21st century
}

by Professor A F M Maniruzzaman

"Simply put, our post-war institutions were built for an inter-national world, but we now live in a global world." - Kofi Annan

$\mathrm{T}$ he present movement toward globalisation has posed a tremendous challenge to traditional international law and, in fact, its various branches including international economic law. The challenge is both horizontal and vertical. It is horizontal in the sense that various new actors such as multinationals, civil society and other non-state actors are increasingly playing an important role in international life and society which is not recognized in traditional international law. (Jessica $T$ Matthews describes a shift away from the state - up down and sideways - to supra-state, sub-state, and, above all, non-state actors in her article "Power shift", Foreign Affairs, January 1997). From the spatial point of view, the territory of international law is increasingly broadening in light of recent developments in the wake of globalisation. The new norms that are rules in the field of international law in various new contexts are also supposed to be evolving vertically to regulate effectively the new phenomenon of globalisation in its various spheres. So from the contextual point of view traditional international law is also evolving vertically.

Seemingly, the power of sovereignty from the state is gradually shifting to market forces in a globalised world giving rise to multifarious norms, standards and rules to deal with the new phenomenon. In the new agenda of globalisation the role of the state is being minimised and that of the non-state actors maximised.

With the phenomenon of globalisation, global governance has also stirred a great debate as to its nature and content. Both concepts are equally important as the latter is the vehicle for the former, ie the ideology. While global governance does not mean world government, various models of global governance have been put forward by schools of thought which may be described as the liberal internationalist, the neo-medievalist and the transgovernmentalist. The liberal internationalists favour the strengthening of international institutions by transferring regulatory authority from the national level to an international institution and the designing of suitable international rules for global governance. However, the liberal internationalists tend to guard against the global dismantling of the regulatory state in this internationalisation process led by globalisation (see AnnMarie Slaughter, "The real new world order", Foreign Affairs, vol 76 (no 5), p183). The neo-medievalists uphold the notion of borderless states and proclaim the end of the nation-state. According to them, power is rapidly shifting from the state to non-state actors which constitute global governance networks in their operations.

The influence of the non-state actors or the international civil society on international affairs and world politics cannot be ignored or taken lightly. Examples abound. The currently oft-quoted ones are the development of the international treaty to ban the use of land mines, the fruition of the Rome statute creating the International Criminal Court, the demise of the Multilateral Agreement on Investment (MAI) under the OECD. Towards the progressive development of international human rights law the influence of the international civil society, ie NGOs, epistemic communities, including that of the scholars of international law, and international activist networks, is well known. The transgovernmentalists find yet a third way for global governance. To them the transgovernmentalism is an emerging new world order in which the individual elements of the state such as courts, regulatory agencies, executives and even legislatures interact directly with their counterparts abroad, thus creating a dense web of relations that constitutes a new transgovernmental order (see AnnMarie Slaughter, ibid). 
Certainly, the new phenomenon of globalisation has posed a big challenge to the notion of nation-state and its sovereignty that we have traditionally known. The traditional international society of states based on the Westphalian notion of sovereignty and the international legal framework in which it has operated so far are equally threatened in the era of globalisation. For traditional international law Westphalian sovereignty is the arch-stone which is now being gradually eroded in the wave of globalisation. However, in one extreme, the hyperglobalizers or the neo-medievalists see the demise of the nation-state and the progressive shift of sovereignty from states to market forces (see, for example, Kenichi Ohmae, The end of the nation state: The rise of regional economics (1995, HarperCollins, London); D Held, Democracy and the global order: From the modern state to cosmopolitan governance (1995, Polity Press, Cambridge, 1999). In contrast, the sceptics of globalisation consider it a non-issue for the nation-state and its sovereignty and in their view globalisation is nothing but a myth (See generally, P Hirst and $\mathrm{G}$ Thompson, Globalization in question: The international economy and the possibilities of governance (Polity Press, Cambridge, 1999); L. Weiss, The myth of the powerless state: Governing the economy in a global era (Polity Press, Cambridge, 1998).

Between these two extremes there are the intergovernmentalists (see Anne-Marie Slaughter, ibid), liberal democratic theorists (see John Rawls, The law of peoples (Harvard University Press, Cambridge Massachusetts; London, England, 1999), transformationalists, and liberal internationalists who view that the nation-state is there to stay, but the modern notion of sovereignty of the nation-state has to be shaped differently from its Westphalian paradigm in order to respond to the phenomenon of globalisation. Whatever the sceptics of globalisation might contend it is true that we cannot run away from the reality of globalisation more than we can from our own shadows. Theories abound as to the modalities of the new notion of sovereignty of the nationstate in the light of globalisation (see Abram Chayes and Antonia Handler Chayes, The new sovereignty : compliance with international regulatory agreements (Harvard University Press, Cambridge, Massachusetts; London, England, 1998).

It is not the nation-state but the nature of its sovereignty that needs to be transformed with globalisation. This is what the transformationalists preach - that globalisation and state sovereignty are not mutually exclusive, rather they are mutually constitutive (see for example S Sassen, Losing control : Sovereignty in an age of globalization (Columbia University Press, New York, 1997); I Clark, Globalization and fragmentation : International relations in the twentieth century (Oxford University Press, Oxford, 1997). The complete denial of sovereignty of a nation-state and its total transfer to the market forces cannot be realistically accepted. In the recent past the demise of the BCCI (Bank of Credit and Commerce International) - jokingly sometimes called the Bank of Cocaine and Crook International because of its international money laundering and other illicit financial activities - and the collapse of the giant transnational corporation Enron because of its fraudulent corporate activities have proved that the role of the regulatory state is quintessential for the stability in the global marketplace, otherwise anarchy and chaos are inevitable. The transfer of sovereignty from the nation-state to market forces will not help the prosperity of the global marketplace and the current of market forces. By the way, who wants to hire a fox to guard the chicken coop in the dead of the night?

The reality at the present time is that the nation-state is constrained to exercise its traditional sovereign authority by various external forces including market forces in the global economy. International lawyers, political scientists, international relations scholars and, above all, globalists, must think of innovative ways how the notion of the nation-state sovereignty can be reconfigured to respond to the phenomenon of globalisation. Similarly, there also needs to be an urgent shift from the traditional international law of co-existence of states - the Westphalian tradition - to the prospective modern international law of co-operation amongst States in the era of globalisation which should be the legal framework for global governance. Some suggestions about the reconfiguration of the traditional notion of sovereignty have been put forward under different banners such as The new sovereignty by Abram and Antonia Chayes (Harvard University Press, 1998), and John Jackson, "Sovereigntymodern: a new approach to an outdated concept" 97 AJIL 782.

The traditional international institutions, in general, and international development agencies, in particular, which are the vehicles of global governance are to be radically reformed. Already there seems to be some initiatives recently undertaken towards that goal. But what is now needed is the radical change in the content of international law geared to the development of the world's poor in the era of economic globalisation and the designing of the international institutions, mainly the international development agencies, for the purpose of global governance in tune with the development of the world's poor being the focal point of globalisation.

It is encouraging to see that the United Nations has already taken the issue of promotion of development in the context of globalisation (see Report of the SecretaryGeneral, Role of the United Nations in Promoting Development in the Context of Globalization and Interdependence, A/54/358 (15 September 1999), and the UNGA resolutions 54/231 (22 December 1999)). Recently, the UN SecretaryGeneral Kofi Annan has taken an innovative initiative, famously known as the Global Compact (GC), the purpose of which is to involve the world's business community with the UN and its relevant agents such as the Office of the OHCHR, the ILO, the UNEP and the UNDP, and other 
major transnational non-governmental organisations, including Amnesty International, the IUCN, Oxfam and ICFTU in an effort to provide the social pillars that a sustainable global economy requires. His proposed GC encompasses nine principles which the corporations are required to act on, drawn from the Universal Declaration of Human Rights, the ILO's Fundamental Principles for Rights at Work and the Rio Principles on Environment and Development :

- support and respect for the protection of internationally proclaimed human rights;

- non-complicity in human rights abuses;

- freedom of association and the effective recognition of the right to collective bargaining;

- the elimination of all forms of forced and compulsory labour;

- the effective abolition of child labour;

- the elimination of discrimination in respect of employment and occupation;

- a precautionary approach to environmental challenges;

- greater environmental responsibility, and

- encouragement of the development and diffusion of environmentally friendly technologies.

These nine principles are universally recognized as "good practices" which the corporations are, in principle, expected to confirm in their respective corporate domains. Under the auspices of the UN these principles are geared to develop global corporate social responsibility. The GC has been both applauded and criticized in different quarters. From the positive perspective, it has been observed: “... apart from constituting an innovative UN 'programme' to change corporate behaviour, the Global compact is also an experiment in devising fundamentally new forms of global governance" (see John Gerald Ruggie, "The United Nations and Globalization: Patterns and Limits of Institutional Adaptation", 9 Global Governance (2003), p 301, at pp 312-3).

It is noteworthy that the $\mathrm{GC}$ is a voluntary initiative and is not a legally binding code. On the international level, apart from certain UN-prescribed and OECD-sponsored voluntary codes, there is so far no legally binding code of conduct for MNCs. As mentioned earlier, the UN has been hosting over the last decade various world conferences the purpose of which, amongst others, is to develop norms and standards for global governance.

As the international economic institutions play a significant role for global economic governance, now the time has come to ponder over the way as to how best these institutions can make their meaningful contributions to a globalisation with a more human face for the greater cause of humanity. Thus the Nobel Prizewinner economist Joseph Stiglitz observes, in Golbalization and its discontents (2002): "The most fundamental change that is required to make globalisation work in the way that it should is a change in governance." He further adds: "It's time to change some of the rules governing the international economic order, to think once again about how decisions get made at the international level - and in whose interests - and to place less emphasis on ideology and to look more at what works."

It should be noted that governance by international economic institutions should be based on certain fundamental principles such as (i) transparency; (ii) democratic accountability; (iii) representation of the public / peoples affected by the institution's activities; (iv) partnership between governments and international institutions.

The international lawyers, international policy makers and international relations scholars of the $21^{\text {st }}$ century will have to walk initially the tight-rope towards a new domain of international law which is very much needed for global governance in the new era.

- This paper was presented to The Society of Legal Scholars' Annual Conference 2004 at the University of Sheffield from 13-16 September.

Professor A F M Maniruzzaman, FRSA, FSALS

Professor of International and Business Law, University of Portsmouth 